(1I) Pohjoismaiden neuvosto

Pohjoismaiden
neuvoston
työjărjestys

SUOMI / 2017 


\section{Pohjoismaiden neuvoston työjärjestys}

ISBN 978-92-893-4783-9 (PRINT)

ISBN 978-92-893-4784-6 (PDF)

http://dx.doi.org/10.6027/ANP2016-786

ANP 2016:786

(C) Pohjoismaiden neuvosto 2017

Ulkoasu: Mette Agger Tang

Paino: Rosendahls

Painos: 300

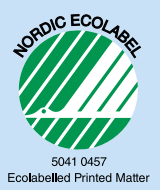

Printed in Denmark

\section{Pohjoismainen yhteistyö}

Pohjoismainen yhteistyö on yksi maailman laajimpia alueellisia yhteistyömuotoja. Yhteistyön piiriin kuuluvat Islanti, Norja, Ruotsi, Suomi ja Tanska sekä Ahvenanmaa, Färsaaret ja Grönlanti.

Pohjoismaista yhteistyötä tehdään politiikan, talouden ja kulttuurin aloilla tärkeänä osana eurooppalaista ja kansainvälistä yhteistyötä. Pohjoismaisen yhteisön tavoitteena on vahva Pohjola vahvassa Euroopassa.

Pohjoismainen yhteistyö pyrkii vahvistamaan pohjoismaisia ja alveellisia etuja ja arvoja globaalissa maailmassa. Maiden yhteiset arvot lujittavat osaltaan Pohjolan asemaa yhtenä maailman innovatiivisimmista ja kilpailukykyisimmistä alueista.

\section{Pohjoismaiden neuvosto}

Ved Stranden 18

DK-1061 København K

Puhelin +4533960200

www.norden.org 
Pohjoismaiden

neuvoston

työjärjestys

SUOMI / 2017 
Pohjoismaiden neuvoston työjärjestys vuodelta 1971 korvattiin uudella työjärjestyksellä, jonka yleisistunto hyväksyi Helsingin sopimuksen 59. artiklan mukaisesti Pohjoismaiden neuvoston istunnossa 13. marraskuuta 1996. Uusi työjärjestys astui voimaan 1. helmikuuta 1997.

Pohjoismaiden neuvoston tarkistettu työjärjestys hyväksyttiin Pohjoismaiden neuvoston 53. istunnossa 30. lokakuuta 2001 sekä Pohjoismaiden neuvoston 57. istunnossa 27. lokakuuta 2005. Tarkistetut työjärjestykset astuivat voimaan välittömästi hyväksymisen jälkeen.

Istunnossa 29. lokakuuta 2008 päätettiin §:n 73 muuttamisesta, ja muutos astui voimaan 1. tammikuuta 2009.

Pohjoismaiden neuvoston työjärjestys vuodelta 2001 korvattiin uudella työjärjestyksellä, jonka yleisistunto hyväksyi Helsingin sopimuksen 59. artiklan mukaisesti Pohjoismaiden neuvoston istunnossa 2. marraskuuta 2011. Uusi työjärjestys astui voimaan 1. tammikuuta 2012.

Pohjoismaiden neuvoston työjärjestys vuodelta 2012 korvattiin uudella työjärjestyksellä, jonka yleisistunto hyväksyi Helsingin sopimuksen 59. artiklan mukaisesti Pohjoismaiden neuvoston istunnossa 3. marraskuuta 2016. Uusi työjärjestys astui voimaan 1. tammikuuta 2017. 


\section{SISÄLLYS}

6 Neuvoston organisaatio ja istunnot

8 Yleiskokous

10 Puheenjohtajisto

12 Valiokunnat

14 Tarkastuskomitea

15 Asioiden valmistelu ennen päätöksentekoa

17 Yleiskokouksen keskustelut ja päätökset

19 Vaalit

22 Muita määräyksiä 


\section{1. luku \\ Neuvoston organisaatio ja istunnot}

\section{§ 1 Neuvoston elimet}

Neuvoston elimiä ovat Helsingin sopimuksen mukaan yleiskokous, puheenjohtajisto ja valiokunnat. Yleiskokous valitsee myös tarkastuskomitean ja vaalikomitean.

\section{§ 2 Istunnot}

Vuosittain pidetään vähintään yksi varsinainen istunto. Sen aikana päätetään seuraavan varsinaisen istunnon ajankohdasta ja paikasta. Puheenjohtajisto voi muuttaa päätöstä, mikäli siihen on erityinen syy.

Muita istuntoja tai teemaistuntoja pidetään puheenjohtajiston päätöksestä tai kun vähintään kaksi hallitusta tai 25 valittua jäsentä pyytää sitä. Puheenjohtajisto päättää ajankohdasta ja paikasta.

\section{§ 3 Yleiskokous}

Yleiskokous on neuvoston ylin päättävä elin. Kokoonpano on säädetty Helsingin sopimuksessa, jonka mukaan yleiskokous voi myös hyväksyä suosituksia, tehdä muita päätöksiä ja antaa lausuntoja yhden tai useamman Pohjoismaan hallitukselle tai ministerineuvostolle.

\section{§ 4 Puheenjohtajisto}

Puheenjohtajisto on neuvoston ylin päättävä elin, kun yleiskokous ei ole koolla, ja sillä on tällöin samat valtuudet kuin yleiskokouksella. Puheenjohtajisto johtaa neuvoston toimintaa ja varmistaa, että se nivoutuu yhteen parlamenttien ja kansainvälisten järjestöjen toiminnan kanssa.

\section{§ 5 Valiokunnat}

Neuvostolla on neljä valiokuntaa: Osaaminen ja kulttuuri Pohjolassa -valiokunta, Kestävä Pohjola -valiokunta, Kasvu ja kehitys Pohjolassa -valiokunta sekä Hyvinvointi Pohjolassa -valiokunta. $\mathrm{Ne}$ valmistelevat oman alansa asioita ennen niiden lopullista käsittelyä. 


\section{§ 6 Tarkastuskomitea}

Tarkastuskomitea harjoittaa yhteispohjoismaisin varoin rahoitettavan toiminnan parlamentaarista valvontaa sekä muuta yleiskokouksen päättämää valvontaa.

\section{§ 7 Vaalikomitea}

Vaalikomitea valmistelee yleiskokouksen toimittamat vaalit ja tekee niihin liittyviä ehdotuksia.

\section{§ 8 Valtuuskunnat}

Helsingin sopimuksessa säädetään valtuuskunnista ja niiden kokoonpanosta.

\section{§ 9 Puolueryhmät}

Valitut jäsenet voivat muodostaa puolveryhmiä. Puolveryhmässä on oltava vähintään neljä jäsentä kahdesta maasta. 


\section{2. luku \\ Yleiskokous}

\section{§ 10 Jäsenet}

Yleiskokous vahvistaa istunnon alussa luettelon osallistuvista jäsenistä ja varajäsenistä. Yleiskokous vahvistaa luettelon muutokset. Niitä ei saa tehdä käynnissä olevan keskustelun tai muun asian käsittelyn aikana.

\section{§ 11 Paikat istuntosalissa}

Valitut jäsenet ja hallitusten edustajat asettuvat istuntosalissa kumpikin omana ryhmänään puheenjohtajiston heille määräämille paikoille.

\section{\$ 12 Presidentti ja varapresidentti}

Varsinaisessa istunnossa valitaan seuraavaksi kalenterivuodeksi presidentti ja varapresidentti, jotka ovat valittuja jäseniä maasta, jossa seuraava varsinainen istunto pidetään.

\section{§ 13 Tarkkailijat}

Norjan, Ruotsin ja Suomen saamelaiskäräjillä on Saamelaisen parlamentaarisen neuvoston kautta tarkkailijan asema ja puheoikeus yleiskeskustelussa ja muulloin puheenjohtajiston päätöksestä.

\section{§ 14 Vieraat}

Nuorten Pohjoismaiden neuvosto (UNR) kutsutaan Pohjoismaiden neuvoston istuntoihin, ja sillä on puheoikeus yleiskeskustelussa ja muulloin puheenjohtajiston päätöksestä.

Puheenjohtajisto voi kutsua istuntoon kansan valitsemien elinten edustajia sekä muita henkilöitä. Puheenjohtajisto päättää tällöin puheoikeudesta.

\section{§ 15 Kokouksen johtaminen}

Kokousta johtaa presidentti tai joku muu puheenjohtajiston jäsen. Henkilö, joka on osallistunut asiaa koskevaan keskusteluun, ei saa johtaa puhetta kyseisessä asiassa.

\section{§ 16 Julkisuus}

Kokoukset ovat julkisia, ellei yleiskokous erityisistä syistä päätä toisin. 


\section{§ 17 Päiväjärjestys}

Yleiskokous vahvistaa istunnon alussa puheenjohtajiston ehdotuksesta päiväjärjestyksen, josta käyvät ilmi istunnossa käsiteltävät asiat ja yleiskokouksen kokoontumisajat. Muutoksista voidaan myöhemmin päättää kahden kolmasosan enemmistöllä.

\section{§ 18 Päätösvaltaisuus}

Yleiskokous on päätösvaltainen, kun läsnä on vähintään 44 valittua jäsentä tai heidän tilalleen tullutta varajäsentä. Asiassa, jossa Helsingin sopimuksen mukaan vain tietyt maat osallistuvat päätöksentekoon, päätösvaltaisuus edellyttää, että läsnä on vähintään puolet kyseisten maiden edustajista.

\section{§ 19 Valmistelupakko}

Jokainen asia on valmisteltava joko puheenjohtajistossa, valiokunnassa tai tarkastuskomiteassa ennen yleiskokouksen lopullista käsittelyä. Vaalikomitea valmistelee vaalit.

\section{§ 20 Pöytäkirjat}

Jokaisessa istunnossa pidetään pöytäkirjaa, josta käyvät ilmi asiat, lausunnot ja tehdyt päätökset sekä niihin liittyvät ehdotukset, vaatimukset, päätöksentekojärjestys, äänestysten tulokset ja puheenvuoroja käyttäneiden henkilöiden nimet. Varsinaisessa istunnossa ja puheenjohtajiston päätöksellä myös muissa kuin varsinaisissa istunnoissa pidetään täydellistä kirjallista pöytäkirjaa.

Muissa istunnoissa pöytäkirjaa voidaan pitää kirjallisessa muodossa tai ääni- tai kuvatallenteena.

\section{§ 21 Täydentävät säännöt}

Yleiskokous vahvistaa istunnon alussa puheenjohtajiston ehdotuksesta istuntoa koskevat täydentävät säännöt. Niitä voidaan muuttaa myöhemmin kahden kolmasosan enemmistöllä, kun puheenjohtajistoa on kuultu. 


\section{3. luko \\ Puheenjohtajisto}

\section{§ 22 Kokoonpano}

Puheenjohtajistoon kuuluvat presidentti, varapresidentti ja enintään 15 valittua jäsentä. Kaikkien maiden ja puolveryhmien on oltava edustettuina.

\section{§ 23 Ahvenanmaa, Färsaaret ja Grönlanti}

Kokouksissa, joissa käsitellään joko Ahvenanmaata, Färsaaria tai Grönlantia koskevia asioita, alueelta valittu jäsen saa olla läsnä, käyttää puheenvuoroja ja tehdä ehdotuksia.

\section{§ 24 Osallistumisoikeus}

Nuorten Pohjoismaiden neuvostolla (UNR) on oikeus osallistua puheenjohtajiston kokouksiin. UNR:n edustaja saa osallistua puheenjohtajiston keskusteluihin mutta ei päätöksentekoon.

\section{§ 25 Kutsu istuntoon ja istunnon päiväjärjestys}

Puheenjohtajisto laatii kutsun istuntoon viimeistään kuukausi ennen istunnon alkua ja ilmoittaa, mitä asioita siinä ehdotetaan käsiteltäväksi. Istunnon alussa puheenjohtajisto tekee ehdotuksen päiväjärjestykseksi, jossa kiinnitetään erityistä huomiota ajankohtaisiin asioihin. Jokainen jäsen voi ehdottaa puheenjohtajistolle päiväjärjestykseen otettavia asioita.

\section{§ 26 Työnjako ja kokouksen suunnittelu}

Puheenjohtajisto päättää asioiden valmistelusta eri elimissä ja huolehtii tarkoituksenmukaisesta suunnittelusta.

Puheenjohtajisto päättää neuvoston elinten vuosittaisesta kokoussuunnitelmasta.

\section{§ 27 Erityistehtävät}

Puheenjohtajisto käsittelee §:ssä 4 mainittujen asioiden lisäksi yleisiä poliittisia ja hallinnollisia asioita, mukaan lukien neuvoston ja Pohjoismaiden ministerineuvoston budjetti, ja valmistelee ulko- ja turvallisuuspoliittisia asioita.

\section{§ 28 Päätökset}

Puheenjohtajisto on päätösvaltainen, kun vähintään puolet jäsenistä on paikalla. Asiassa, jossa Helsingin sopimuksen mukaan vain tietyt maat 
osallistuvat päätöksentekoon, päätösvaltaisuus edellyttää, että läsnä on vähintään puolet kyseisten maiden edustajista.

Mikäli äänet menevät tasan, kokouksen puheenjohtajan ääni ratkaisee.

Päätökset voidaan tehdä kirjallisella menettelyllä, mikäli päättävät jäsenet ovat siitä yksimielisiä. Kirjallinen vastaus on annettava.

\section{§ 29 Päätöspöytäkirjat}

Puheenjohtajisto, valiokunnat ja komiteat laativat kokouksistaan päätöspöytäkirjat. Kaikki päätettävät asiat hyväksytään kokouksessa. Kokouksen puheenjohtajan hyväksymä pöytäkirja lähetetään viimeistään kahden viikon kuluttua kokouksesta, ja muutokset tehdään seuraavassa kokouksessa.

Pöytäkirjat julkaistaan Pohjoismaiden neuvoston verkkosivustossa.

\section{§ 30 Kokoukset}

Puheenjohtajiston kokoukset eivät ole julkisia, ellei se päätä toisin. Valtuuskuntien ja puolveryhmien sihteeristöjen edustajilla on läsnäolo-oikeus, ellei jokin erityinen seikka estä sitä. Puheenjohtajisto voi kutsua kokouksiinsa myös muita henkilöitä osallistumaan ja käyttämään puheenvuoroja.

\section{§ 31 Delegointi}

Puheenjohtajisto voi delegoida päätöksenteko-oikeutensa asioissa tai asiakokonaisuuksissa toiselle neuvoston elimelle, yhdelle tai useammalle puheenjohtajiston jäsenelle tai neuvoston johtajalle.

\section{§ 32 Työryhmät ja muut valmisteluelimet}

Puheenjohtajisto voi asettaa erityistehtäviä varten työryhmiä ja päättää tällöin niiden kokoonpanosta ja toimeksiannosta, josta käyvät ilmi tehtävät, valtuudet ja aikarajat. Tällaiset aloitteet eivät vaikuta §̧:n 19 mukaiseen varsinaiseen asianvalmisteluun.

\section{§ 33 Kertomus}

Puheenjohtajisto jättää vuosittain yleiskokoukselle kertomuksen neuvoston toiminnasta. 


\section{4. luku \\ Valiokunnat}

\section{§ 34 Nimeäminen ja kokoonpano}

Valiokunnissa on 16-18 jäsentä. Jokaisella valiokunnalla tulee olla puheenjohtaja ja varapuheenjohtaja. Yleiskokous valitsee jäsenet sekä puheenjohtajan ja varapuheenjohtajan. Sekä puheenjohtajan että varapuheenjohtajan ollessa estynyt valiokunta nimeää kokoukselle puheenjohtajan.

\section{§ 35 Osallistumisoikeus}

Hallituksen, maakuntahallituksen, maakunnan hallituksen tai Naalakkersuisutin jäsen voi osallistua valiokunnan työhön mutta ei päätöksentekoon.

Mikäli valiokunnassa ei ole edustajaa Ahvenanmaalta, Färsaarilta tai Grönlannista, niitä edustava valittu jäsen voi osallistua kokoukseen. Valiokunnan tanskalaisten tai suomalaisten jäsenten kanssa voidaan sopia, että tällainen jäsen voi osallistua päätöksentekoon tanskalaisen tai suomalaisen jäsenen sijaan.

Nuorten Pohjoismaiden neuvostolla (UNR) on oikeus osallistua valiokuntakokouksiin. UNR:n edustajat saavat osallistua valiokunnan työhön mutta eivät päätöksentekoon.

\section{§ 36 Laajennettu tarkkailijan asema}

Suomen, Ruotsin ja Norjan saamelaiskäräjillä on Saamelaisen parlamentaarisen neuvoston kautta laajennettu tarkkailijan asema, johon kuuluu oikeus osallistua valiokuntakokouksiin silloin, kun niissä käsitellään saamelaisia koskevia asioita. Valiokunnat päättävät, mihin kokouksiin saamelaisten edustajia kutsutaan. Osallistumisoikeuteen ei kuulu äänestysoikeus.

\section{§ 37 Päätökset}

Tässä sovelletaan §:n 28 ja §:n 29 määräyksiä.

\section{§ 38 Kokoukset ja julkisuus}

Valiokunnat pitävät kokouksia §:n 26 toisen kappaleen mukaisesti. Valiokunnan puheenjohtaja voi päättää ylimääräisen kokouksen 
pitämisestä, ja ylimääräinen kokous on kutsuttava koolle, mikäli yksi neljäsosa valiokunnan varsinaisista jäsenistä vaatii sitä.

Kokoukset eivät ole julkisia, ellei valiokunta erityistapauksessa päätä toisin. Muilta osin sovelletaan §:n 30 määräyksiä.

\section{§ 39 Kokousasiakirjat}

Kokouskutsu tulee lähettää kuukausi ennen kokousta. Päiväjärjestys siihen kuuluvine aineistoineen on toimitettava kaikille asianomaisille viikko ennen kokousta.

\section{§ 40 Kansalaislähetystöt}

Kansalaislähetystöille voidaan antaa lupa näkemysten esittämiseen puheenjohtajiston määräämien suuntaviivojen mukaisesti.

\section{§ 41 Tehtävät}

Valiokuntien tulee puheenjohtajiston niille osoittamien asioiden valmistelun ohella seurata oman alansa kehitystä.

Kullakin valiokunnalla on oltava ajankohtainen toimintasuunnitelma.

§ 42 Yhteistyö kansallisten ja kansainvälisten valiokuntien kanssa Valiokuntien on pyrittävä tekemään yhteistyötä parlamenttien ja kansainvälisten järjestöjen vastaavien elinten kanssa.

\section{§ 43 Muut säännöt}

Puheenjohtajisto voi päättää valiokuntien työn yleisistä säännöistä. 


\section{5. luku \\ Tarkastuskomitea}

\section{§ 44 Nimeäminen ja kokoonpano}

Yleiskokous valitsee tarkastuskomitean puheenjohtajan, varapuheenjohtajan sekä viisi muuta jäsentä ja näille henkilökohtaiset sijaiset. Kukaan heistä ei saa olla tai olla ollut edellisen kalenterivuoden aikana puheenjohtajiston jäsen tai varajäsen. Jokaisen maan on oltava edustettuna.

Tässä sovelletaan §:n 23 ja §:n 30 määräyksiä. Ylimääräisen kokouksen pitämisestä päättää puheenjohtaja ja ylimääräinen kokous on kutsuttava koolle, mikäli kolme jäsentä vaatii sitä.

Sekä puheenjohtajan että varapuheenjohtajan ollessa estynyt valiokunta nimeää kokoukselle puheenjohtajan.

\section{§ 45 Päätökset}

Tarkastuskomitea on päätösvaltainen, kun läsnä on neljä jäsentä. Tässä sovelletaan §:n 28 toisen ja kolmannen kappaleen ja §:n 29 määräyksiä.

\section{§ 46 Erityistehtävät}

Tarkastuskomitea voi antaa puheenjohtajistolle lausuntoja Helsingin sopimuksen, muiden pohjoismaista yhteistyötä koskevien sopimusten, neuvoston työjärjestyksen ja muiden sisäisten määräysten tulkinnasta. 


\section{Iuko \\ Asioiden valmistelu ennen päätöksentekoa}

\section{§ 47 Ehdotuksen tekeminen}

Kaikista asioista on tehtävä kirjallinen ehdotus, johon sisältyy päätösehdotus. Ehdotuksen voi perua sen tehnyt elin tai ehdotuksen tehneet jüsenet.

Varajäsen, joka ei ole varsinaisen jäsenen tilalla, voi allekirjoittaa jäsenehdotuksen, mutta hän ei voi itse tehdä ehdotusta.

\section{§ 48 Neuvonpito ja lausunnot}

Mikäli asia kuuluu usean elimen toimialaan, niiden on neuvoteltava siitä keskenään. Puheenjohtajisto, valiokunnat ja tarkastuskomitea voivat pyytää neuvoston muilta elimiltä lausuntoja valmisteluvaiheessa olevasta asiasta.

\section{§ 49 Mietintö}

Asian valmistelusta vastaava elin laatii mietinnön, johon sisältyy perusteltu päätösehdotus sille elimelle, joka käsittelee asian loppuun.

Jäsenellä on oikeus liittää mietintöön tai lausuntoon varauma క:n 48 mukaisesti. Mikäli varauma sisältää päätösehdotuksen, sen on noudatettava mietinnön tai lausunnon järjestystä.

\section{§ 50 Lopullisen käsittelyn ajankohta}

Mietinnön saa käsitellä yleiskokouksessa aikaisintaan seuraavana päivänä siitä, kun jäsenet ovat saaneet sen, ellei yleiskokous päätä muuta kahden kolmasosan enemmistöllä.

\section{§ 51 Keskustelumahdollisuus}

Jäsenillä on oltava tilaisuus keskusteluun ennen kuin yleiskokous tekee päätöksen asiassa.

\section{§52 Asian palauttaminen}

Yleiskokous voi palauttaa mietinnön elimelle, joka on laatinut sen. Jos tätä ehdotetaan meneillään olevan keskustelun aikana, keskustelu on keskeytettävä ja jäsenille annettava oikeus ilmaista mielipiteensä ja päättää ehdotuksesta. Mikäli tämä hyväksytään, 
asian käsittely keskeytetään. Muussa tapauksessa keskustelua jatketaan. Uusi palauttamisehdotus käsitellään keskustelun päätyttyä.

\section{§ 53 Asian lykkääminen}

Yleiskokous voi lykätä asian käsittelyn myöhempään ajankohtaan istunnon aikana tai myöhempään istuntoon. Jälkimmäinen vaatii kahden kolmasosan enemmistön ja edellyttää, että asia valmistellaan uudelleen. Muilta osin noudatetaan §:n 52 määräyksiä.

\section{§54 Muutosehdotus}

Mikäli valittu jäsen haluaa esittää käsiteltävään asiaan ehdotuksen, joka ei sisälly mietintöön, se on tehtävä kirjallisesti ja jaettava jäsenille, ellei sisältö ole ilmeisen selvä. Jäsen voi saada meneillään olevan keskustelun aikana puheenvuoron välittömästi ja esittää muutosehdotuksen perustelematta sitä. Asia voidaan lykätä myöhempään ajankohtaan istunnon aikana, mikäli yksi kolmasosa läsnä olevista valituista jäsenistä kannattaa lykkäämistä. 


\section{7. luku \\ Yleiskokouksen keskustelut ja päåtökset}

\section{§ 55 Puhujalista}

Puheenjohtajisto voi määrätä puhujalistaa koskevat säännöt.

Mikäli sääntöjä ei ole, noudatetaan sitä järjestystä, jossa puhujalistalle on ilmoittauduttu.

\section{§ 56 Oikeus vastauspuheenvuoroon}

Jäsenelle, jota varsinainen puheenvuoro suoraan koskee, on annettava mahdollisuus enintään kahteen vastauspuheenvuoroon puhujalistasta riippumatta. Jollei §:n 21 mukaisissa säännöissä toisin määrätä, kokouksen puheenjohtaja voi antaa myös toiselle jäsenelle oikeuden enintään kahteen vastauspuheenvuoroon.

Vastauspuheenvuoro saa sisältää ainoastaan selvityksen, oikaisun tai vastineen ja kestää korkeintaan kaksi minuuttia, ellei §:n 21 mukaisissa säännöissä toisin määrätä.

\section{§ 57 Puheaika}

Yleiskokous voi puheenjohtajiston tai kokouksen puheenjohtajan ehdotuksesta rajoittaa puheenvuorojen pituutta keskustelussa tai istunnon tietyssä osassa. Tällainen päätös voidaan tehdä meneillään olevan keskustelun aikana.

\section{§58 Keskustelun päättäminen}

Yleiskokous voi puheenjohtajan tai viiden valitun jäsenen ehdotuksesta päättää kahden kolmasosan enemmistöllä, että asiaa koskeva keskustelu päätetään. Tällaisesta ehdotuksesta ei saa keskustella.

\section{§ 59 Päätökset}

Kun asiaa koskeva keskustelu on päättynyt, yleiskokous tekee päätöksen. Kaikista asioista päätetään äänestämällä.

\section{§ 60 Sisäiset päätökset}

Sisäiset päätökset dokumentoidaan Pohjoismaiden neuvoston vuosikertomukseen §:n 33 mukaisesti. 


\section{§ 61 Äänestys}

Äänestys on avoin ja se toimitetaan nimenhuudolla tai äänestyslaitteella. On mahdollista äänestää kyllä tai ei tai jättää äänestämättä. Mikäli äänet menevät tasan, ratkaisee arpa.

Äänestyksessä asetetaan ensin vastakkain toisistaan poikkeavat vastaehdotukset, kunnes jäljelle jää vain yksi. Se asetetaan lopullisessa äänestyksessä pääehdotusta vastaan.

\section{§ 62 Kysymykset}

Valitut jäsenet voivat esittää kysymyksiä hallitukselle, maakuntahallitukselle, maakunnan hallitukselle, Naalakkersuisutille tai ministerineuvostolle. Suullinen kysymys on esitettävä ja siihen on vastattava erillisen kyselytunnin aikana, joka järjestetään puheenjohtajiston ehdotuksesta §:ssä 17 mainittujen sääntöjen mukaisesti. Kirjalliseen kysymykseen on vastattava viimeistään kuuden viikon kuluessa siitä, kun vastaanottaja on saanut sen. 


\section{8. luku \\ Vaalit}

\section{§ 63 Vaalikomitea}

Vaalikomiteassa on seitsemän jäsentä. Yleiskokous valitsee jäsenet. Vaalikomitea valitsee keskuudestaan puheenjohtajan ja varapuheenjohtajan.

\section{§ 64 Päätökset}

Vaalikomitea on päätösvaltainen, kun läsnä on neljä jäsentä. Tässä sovelletaan §̧:n 28 toisen ja kolmannen kappaleen ja §:n 29 määräyksiä.

\section{§ 65 Nimeäminen}

Puolveryhmät ja puolveryhmiin kuulumattomat jäsenet saavat vaalikomitean asettaman määräajan sisällä nimetä ehdokkaat yleiskokouksen toimittamiin vaaleihin. Valtuuskunnat nimeävät kuitenkin ehdokkaat presidentiksi ja varapresidentiksi sekä Pohjoismaiden investointipankin tarkastuskomitean ja Pohjoismaisen kulttuurirahaston hallituksen jäseniksi.

Nimeämisessä on pyrittävä sekä maiden että sukupuolten väliseen tasapainoon ja siinä on mahdollisuuksien mukaan huomioitava myös kansalliset valiokuntajäsenyydet.

\section{§ 66 Toimikaudet}

Jokainen varsinainen tehtävä koskee seuraavaa kalenterivuotta, ellei erikseen ole säädetty muuta.

\section{§ 67 Vaalikomitean ehdotus}

Vaalikomitea laatii ehdotuksen nimistä ja tarvittaessa jäsenten lukumäärästä. Tällöin on otettava huomioon se, mitä todetaan §:n 65 toisessa kappaleessa.

Yleiskokous voi palauttaa komitean ehdotuksen mutta ei muuttaa sitä. Ellei ehdotusta hyväksytä, toimitetaan vaali suljetulla lippuäänestyksellä §:n 68 tai §:n 69 mukaisesti. 


\section{§ 68 Yhden henkilön valinta}

Jos tarkoituksena on valita vain yksi henkilö, vaali toimitetaan suljetulla lippuäänestyksellä, mikäli yksi valittu jäsen vaatii sitä.

\section{§ 69 Suhteellinen vaali}

Jos tarkoituksena on valita kaksi tai useampia henkilöitä, toimitetaan suhteellinen vaali, mikäli sitä vaativien jäsenten lukumäärä vastaa läsnä olevien lukumäärää jaettuna valittavien lukumäärällä, johon lisätään yksi.

\section{§ 70 Ehdokaslistat}

Mikäli toimitetaan suhteellinen vaali, kokous on tarvittaessa keskeytettävä, niin että ehdokaslistojen laatimiseen jää kohtuullisesti aikaa. Listalla voi olla enintään yhtä monta nimeä kuin on valittavia jäseniä ja ehdokkaiden on oltava siinä järjestyksessä kuin heidät toivotaan valittavan. Listassa tulee olla vähintään kahden valitun jäsenen allekirjoitus ja se on toimitettava sihteeristölle viimeistään kokouksen puheenjohtajan määräämänä ajankohtana. Listat numeroidaan niiden saapumisjärjestyksessä. Äänestäjä merkitsee äänestyslippuun ehdokaslistan numeron.

\section{§ 71 Vaalimenetelmä}

Suhteellisessa vaalissa äänestystulos määräytyy kokonaislukumenetelmän (d'Hondtin menetelmä) mukaisesti. Jokaisella äänestyskierroksella valitaan yksi henkilö listalta, jonka vertailuluku on suurin. Listan vertailuluku on sama kuin listan saamien äänten lukumäärä ennen kuin listalta on valittu ketään. Sen jälkeen kun yksi henkilö on valittu, luku jaetaan kahdella, kun kaksi henkilöä on valittu, luku jaetaan kolmella jne. Mikäli äänet tai vertailuluvut menevät tasan, ratkaisee arpa. Kunkin listan paikat jaetaan siinä järjestyksessä kuin ehdokkaat on merkitty listalle.

\section{§ 72 Täytevaali}

Mikäli istuntojen välillä tarvitaan täytevaalia, sen suorittaa puheenjohtajisto §:ssä 65 säädetyn nimeämismenettelyn mukaisesti puheenjohtajiston määräämän ajan kulvessa ja vaalikomitean ehdotuksen pohjalta. 


\section{§ 73 Sijaiset}

Jäsenen ollessa estynyt muussa elimessä kuin yleiskokouksessa tai tarkastuskomiteassa puolveryhmä valitsee sijaisen, jonka on oltava neuvoston jäsen tai varajäsen. Puolueryhmiin kuulumattomille jäsenille puolve valitsee sijaisen. Ahvenanmaan, Färsaarten ja Grönlannin valtuuskunnat valitsevat sijaisen varsinaisen jäsenen ollessa estyneenä. Samat säännöt koskevat sijaista kaikissa elimissä kuin muita jäseniä. 


\section{9. luku}

\section{Muita määräyksiä}

\section{§ 74 Kielet}

Pohjoismaiden kieliä pidetään yhdenvertaisina neuvoston kokouksissa. Työkielet ovat norja, ruotsi ja tanska. Tarvittaessa järjestetään tulkkaus suomeksi ja suomesta sekä islanniksi ja islannista. Tärkeät asiakirjat on käännettävä Pohjoismaiden kielille.

\section{§ 75 Tehtävä neuvoston elimissä}

Valitun jäsenen on oltava jäsenenä vähintään yhdessä elimessä eli joko puheenjohtajistossa, valiokunnassa tai tarkastuskomiteassa, ellei muuhun ole erityistä syytä.

\section{§ 76 Esteellisyys}

Kukaan ei saa osallistua sellaisen asian käsittelyyn, joka koskee suoraan häntä tai hänen läheistään.

\section{§ 77 Järjestyssäännöt}

Kukaan ei saa puhua kokouksessa toisesta sopimattomalla tavalla tai käyttää loukkaavia ilmaisuja tai muulla tavoin sanoin tai teoin käyttäytyä hyvän järjestyksen vastaisesti. Häiritsevästi käyttäytyvä kuulija voidaan poistaa salista. Mikäli kokouksen aikana syntyy epäjärjestystä, puheenjohtaja voi tyhjentää salin.

\section{§ 78 Neuvoston sihteeristö}

Kokousten toteuttamisesta vastaa neuvoston sihteeristö yhteistyössä sen maan valtuuskunnan sihteeristön kanssa, jossa kokous pidetään.

Puheenjohtajisto palkkaa henkilöstön ja määrää neuvoston sihteeristön työtä koskevista säännöistä. Sihteeristö valmistelee asiat, joita käsitellään neuvoston elimissä, ja sen tulee tehdä siinä yhteydessä yhteistyötä valtuuskuntien ja puolueryhmien sihteeristöjen kanssa.

\section{§ 79 Valtuuskunnat}

Valtuuskunnat valitsevat keskuudestaan puheenjohtajan ja varapuheenjohtajan.

Jokaisen valtuuskunnan on valvottava, että päätöksiä seurataan kansallisesti. 


\section{§ 80 Puolueryhmien rekisteröityminen}

Puheenjohtajisto määrää puolveryhmien ja niiden edustajien rekisteröitymistä koskevat säännöt.

\section{§ 81 Puolueryhmätuki}

Puolveryhmä saa tukea neuvostossa toimimista varten, jos se ennen tukivuotta toimittaa sihteeristölle selvityksen siitä, että se täyttää §:n 9 vaatimukset. Jos puolveryhmässä tapahtuu sellaisia muutoksia, ettei se enää täytä näitä vaatimuksia, se saa seuraavana vuonna ainoastaan edustajapaikkaperusteista tukea jäljellä olevista jäsenistä.

Kaikki ryhmät saavat samansuuruisen perusosan sekä jokaisesta jäsenestä maksettavan edustajapaikkaperusteisen summan. Puheenjohtajisto päättää summat kyseisen vuoden budjetin yhteydessä.

Puolveryhmätukea koskevista täydentävistä säännöistä päättää puheenjohtajisto.

\section{§ 82 Yksittäiselle jäsenelle myönnettävä tuki}

Puolveryhmään kuulumaton jäsen saa saman edustajapaikkaperusteisen summan, paitsi jos jokin jo olemassa oleva puolveryhmä saa hänestä edustajapaikkaperusteista tukea §:n 81 mukaisesti.

\section{§ 83 Tilinpäätös}

Puolveryhmien ja puolueryhmään kuulumattomien jäsenten, jotka ovat saaneet tukea §:n 81 tai §:n 82 nojalla, tulee jättää 15. toukokuuta mennessä edellistä vuotta koskeva tilinpäätös. Puheenjohtajisto tarkastaa tilinpäätöksen ensimmäisessä toukokuun 15. päivän jälkeen pitämässään kokouksessa ja voi päättää tilinpäätöstä koskevista lisäsäännöistä.

\section{§ 84 Työjärjestyksestä poikkeaminen}

Yleiskokous voi erityistilanteessa poiketa tästä työjärjestyksestä puheenjohtajiston ehdotuksesta ja kahden kolmasosan enemmistöllä.

Tämä työjärjestys astuu voimaan 1. tammikuuta 2017. 
$\mathbb{1}$

Pohjoismaiden neuvosto

Ved Stranden 18

DK-1061 København K

www.norden.org

Pohjoismaiden neuvosto perustettiin 1952 Islannin, Norjan, Ruotsin ja Tanskan hallitusten ja parlamenttien yhteistyöelimeksi. Suomi liittyi siihen 1955. Pohjoismaiden ministerineuvoston perustamisen jälkeen 1971 neuvostosta tuli parlamentaarikoiden yhteistyöelin.

Pohjoismaiden neuvostoon kuuluu 87 Pohjoismaiden parlamenttien nimeämää kansanedustajaa. Färsaarten ja Grönlannin valtuuskunnat kuuluvat Tanskan valtuuskuntaan ja Ahvenanmaan valtuuskunta Suomen valtuuskuntaan. Pohjoismaiden neuvosto on aloitteita tekevä ja neuvoa antava elin. Sen tehtävänä on valvoa ja edistää pohjoismaista yhteistyötä. Neuvoston elimiä ovat yleiskokous, puheenjohtajisto ja valiokunnat. 